\title{
Robot Arm Design for Coffee Maker Arduino Based
}

\author{
Ari Waluyo ${ }^{1 *}$ Asni Tafrikhatin ${ }^{2}$ Sri Rahandika Heri ${ }^{3}$ \\ 1,2,3 Politeknik Dharma Patria, 54316, Indonesia \\ ${ }^{*}$ Corresponding author. Email: ari.hardware@yahoo.com
}

\begin{abstract}
Coffee is one of the favorite drinks in Indonesia. The way of making coffee is brewing and using a machine. Most coffee machines use a manual system, so they are less efficient and less attractive. The purpose of this study was to design a coffee machine using a robotic arm. This coffee machine can a be controlled remotely using a smartphone. Design of robot arm to coffee maker included hardware and software design. Hardware design used blender, while the software design used Arduino IDE. Design of robot arm to coffee maker produces 4 parts, namely (1) the controller uses a smartphone, (2) the receiver will check the water level, water temperature, and water adequacy, (3) notification via voice, and (4) the robot arm will make a cup of brewed coffee. Automatic coffee maker does not only use a coffee machine but also it can be used by robot arm.
\end{abstract}

Keywords: Arduino, Coffee Maker, Robot Arm.

\section{INTRODUCTION}

Coffee is one of the drinks favored by Indonesians. This is evidenced by the results of a survey which states that in 2011 the level of coffee consumption in Indonesia reached 800 grams / capita / year [1]. People consume coffee because it has benefits: blocking genes by modulating some of the enzymes involved in carcinogenic detoxification; these molecules also alter xenotoxic metabolism by inducing the enzyme glutathione-S-transferase and inhibiting Nacetyltransferase. [2]. Basically, there are two types of coffee circulating in Indonesia, namely brewed coffee and instant coffee [1]. Coffee brewed is koi made from ground coffee beans and then given boiling water, leaving the dregs.

Coffee fans range from young to old and do not recognize gender [3]. In the past, coffee lovers aimed to enjoy a cup of coffee and relax. Currently, coffee lovers are starting to experience a cultural shift. This cultural shift was caused by changes in lifestyle which began to mix with western culture.

The high number of coffee enthusiasts in Indonesia has resulted in very diverse coffee marketing. One popular example of coffee marketing is the coffee cafe. Coffee is costly drink now. Besides its good taste, coffee is also marketed with the atmosphere when drinking coffee [4]. The atmosphere of the coffee cafe is designed in such a way as to attract visitors. Coffee cafe designs that are busy with visitors include modern, luxurious, ancient, and unique designs.

The method of serving coffee also varies. The method of serving coffee is adjusted according to market share and sales location. Coffee made using the manual method is usually located in a mall or a large location and can be made as a hangout place. Meanwhile, coffee served with a machine is usually located at airports, supermarkets and stations.

Based on the description above, someone enjoying coffee is influenced by several factors including the type of coffee, the method of serving, and the location. These three factors greatly influence a person to enjoy coffee. Therefore, we need an innovation from these three factors. Robots are also an interesting thing in coffee making.

Robot is a design from various kinds of science which is used as a tool that has been designed systematically and complex. The robot issues the output according to what is needed in executing or executing commands. Humans use robots as tools that facilitate various kinds of human activities and jobs. The robotics technique contains various elements used and programming techniques. Various opinions have been found about robotics, concluding that robotics is composed of 2 elements, namely elements of hardware and software.

The hardware element consists of the microcontroller, design, input, and output. The microcontroller is the brain 
part of the processing of a robot that regulates all components connected to the microcontroller with a program that has been implanted into the microcontroller, it will be executed according to the timing and conditions determined by the programmer [5]. The design is a framework for the robot and the measured parts to be occupied by the components that are controlled by the microcontroller. Input (component) has the function of taking input so that it is processed by the microcontroller to carry out the next action according to the program being executed. Such as a temperature sensor whose value is taken and calculated to be visualized by the output component. Output (component) has a function as the output of a microcontroller processing. Like a servo motor which is rated the degree angle based on the specified time.

Software elements consist of firmware and programs. Firmware is a collection of basic software that is composed of binary collections which are later manipulated by programming languages to form an action. In this study, the Arduino uses the ATMEGA IC and the Arduino bootloader as the default firmware from the Arduino manufacturer. The Arduino interface uses the Arduino IDE. The program is a command line that is input to the microcontroller and stored in ROM memory and executed by the microcontroller in accordance with the prefix or setup line and then the repeating line or loop.

Robot arm or arm is one of the design results of robotics techniques. Robotics uses motor components as joints like humans, allowing a robotics arm to be created in the presence of hardware and software elements [6]. The making of the arms is done systematically and mathematically because the robotic arm will be commanded using a degree or vector. These results will be obtained with accurate movement results in every targeted angle. Robot arms are bones or arms and robot joints [8]. These parts are arranged systematically so that the robot arm has complex and balanced movements. The use of robotic arms in developed countries is more likely to be used as a sophisticated industrial tool and has a capacity that cannot be done by humans.

Arduino is a name for the microcontroller created by Hernando Barragan [6]. The purpose of making Arduino is to make it easier for students to make designs and interactions, Arduino uses the Atmega family processor whose software has its own programming language. Arduino continues to grow and has a series that has different capacities and functions. There are 2 series that the author uses by considering the advantages of each Arduino series in conducting research, namely Arduino Uno and Arduino Nano. The most widely used Arduino Uno has 14 digital pins and 6 analog pins and uses ATMega328 as its microcontroller making the Uno series more familiar to use and has good stability.

Arduino Nano is an Arduino with this small and very simple size, saving a lot of facilities [7]. FTDI for programming via Micro USB. Digital I / O pins, and 8 Pins Analog input (more than Uno). Some are using ATMEGA168, or ATMEGA328 [9]. Arduino Uno and Arduino nano are a collaboration between 2 types of Arduino where Uno is used as a control robot because Uno has a good level of resistance in the use of voltages above 6 volts [10], while Nano is used because of its efficiency in electricity usage, which is below 5 volts as well as being a good input control because it has a slightly more number of pins and has a physical size that does not take up too much space.

\section{METHOD}

This research method through several stages of research is presented in Figure 1.

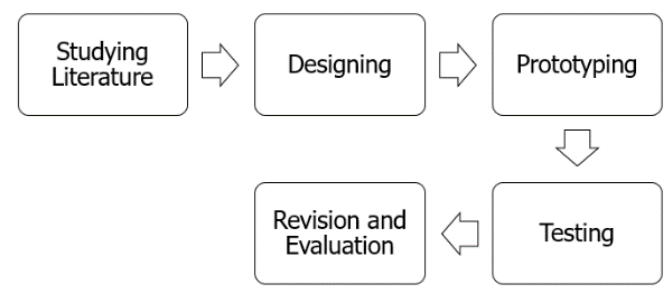

Figure 1 Research methods

\subsection{Studying Literature}

The first stage of this research is information gathering. Gathering information is the stage of collecting various existing information about solving the problems found.

\subsection{Designing}

Product design is designing a product to solve problems that have been found. Product design includes both software and hardware design.

\subsection{Prototyping}

Product manufacturing is the process of making a product that has been developed.

\subsection{Testing}

Testing is trying out a product developed by testing the components that have been installed.

\subsection{Revisions and Evaluation}

Product revision is to improve the product being developed. This fix is based on an error in product testing. Apart from that, it also evaluates the product.

\section{RESULT AND DISCUSSION}

Every robotic development always involves various kinds of research and parties to facilitate its formation. 
The robotic arm is one of the results of robotics techniques which are built from various complex and systematic designs. The purpose of this research is to find new techniques with the output of a brewed coffee or we call it Moci (Microcontroller Coffee Indonesia). Arduino nano as a robot arm control and Arduino Uno as command control for both analog and wireless input are very familiar to people who really like things that are easy to use such as smartphones or digital input such as a keypad. This research develops a new technique in a different way from what is often used by other robotic programmers in order to obtain accurate results later. Equipped with a robotic arm as a coffee maker arm and a receiver as a recipient of the orders as well as other design needs such as water heating, coffee boxes, sugar containers. This research got good results because the level of smoothness of the arm movement is very visible and also the accuracy of the robot arm is very precise in running programs with this new technique. The stages of making this robot arm are as follows.

\subsection{Study Literature}

At this stage the writer reads various literature and journals. The result of literature and journal searches is an analysis of the limitations of the development of the coffee robot arm. These limitations are (a) this project can be used by using electrical power and a smartphone as an input for ordering coffee only in the 50 meters range using a Bluetooth connection, (b) the design side that has not used good quality materials because it is still in the stage. Beta or trial although it can operate properly, the authors still limit it, (c) the robot arm material still uses acrylic material so that it is not too dangerous when using metal. It is mandatory to consider the safety side of the circuit because the movement of the servo motor has sufficient torque. large, this research decided to still use acrylic material as a robot arm, and (d) as a support for all components using wood. Wood was chosen because it does not conduct electric current, which is the right choice to prevent leakage of electric current, no matter how small the voltage value

\subsection{Designing}

The design of the coffee maker robot arm consists of block diagrams, hardware design, electronic design, and application design. The block diagram of the coffee maker robot arm is presented in Figure 2.

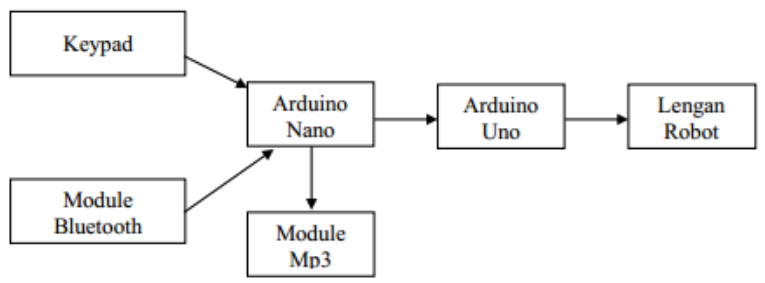

Figure 2 Diagram block of coffee maker robot arm
Based on Figure 2, this approach uses a Bluetooth module and a keypad as input or input parts. The two input components are controlled by a microcontroller, namely Arduino nano, which will retrieve command data from the Bluetooth module and keypad to make decisions about the commands that will be sent to the robot arm controller. Therefore, lighten the burden on the robot arm controller because there is an input part that is controlled by the Arduino nano controller. The hardware design of the coffee maker robot arm is presented in Figure 3.

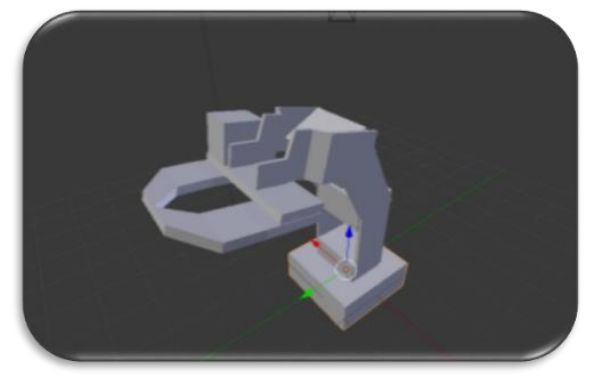

Figure 3 Design of a coffee maker robot arm

The electronic circuit design of the coffee maker robot arm is presented in Figure 4.

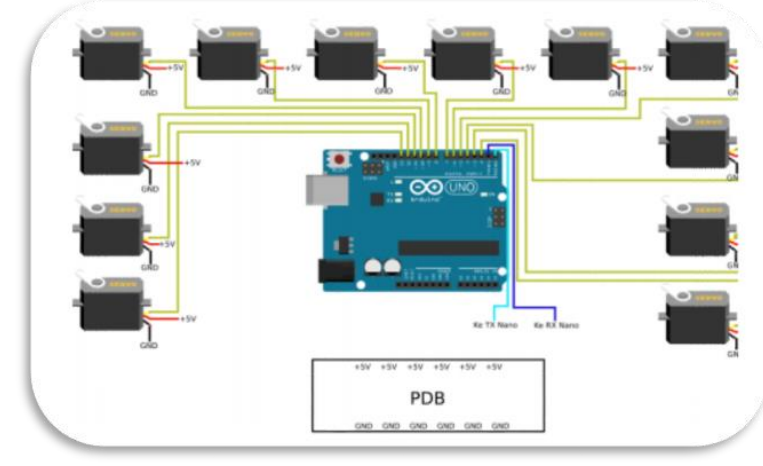

Figure 4 Electronic circuit of coffee maker robot arm

Based on Figure 4, Arduino Uno controls 12 servo and has a communication line at pin 0 and pin 1 as communication between the receiver (Arduino Nano). Arduino is equipped with a power distribution (PDB) aimed at stabilizing the voltage so that the servo and Arduino can work stably. In addition, as a source of voltage Arduino, the author decided to provide $5-7$ volts of power because based on the results of the analysis all Arduino types are very stable on a $5-7$ volt power source. The design of the coffee maker robot arm android application is presented in Figure 5.

Based on figure 5, how the android application developed is as follows. First, when opening the application's home page there will be a Bluetooth connection option that will be used. After Bluetooth is connected to the coffee maker, the application will display a selection of the number of copies made and the amount of sugar you want. If you click "make", then the robot arm will make coffee according to the amount of 
coffee and the amount of sugar you want, while clicking "back" will return to the start menu.

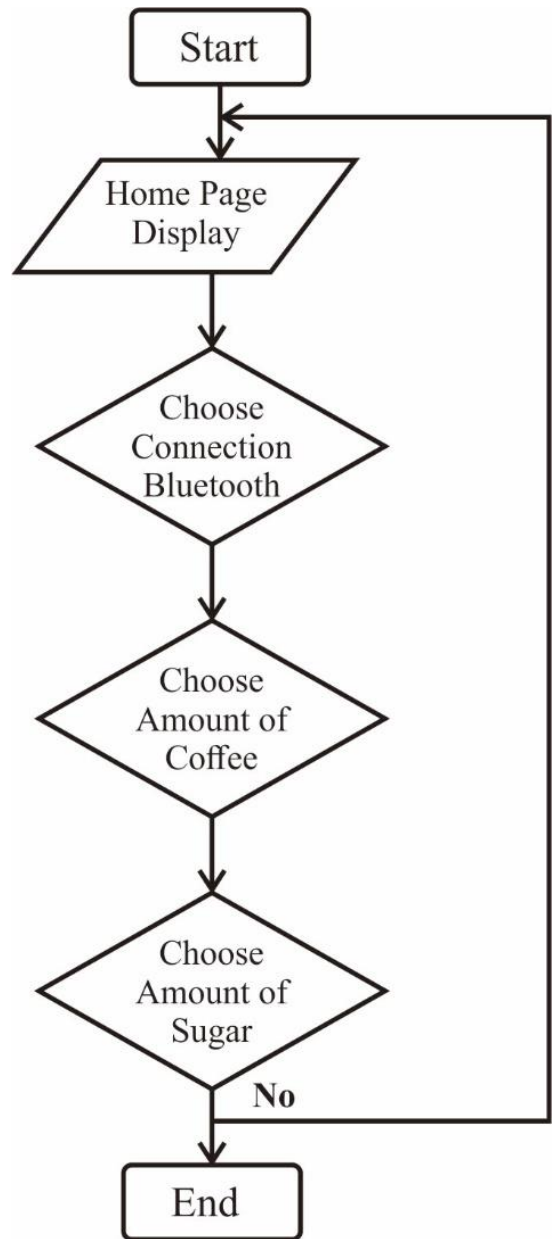

Figure 5 Application design with a coffee maker robot

\subsection{Prototyping}

The results of the prototype robot arm of the coffee maker are presented in Figure 6.

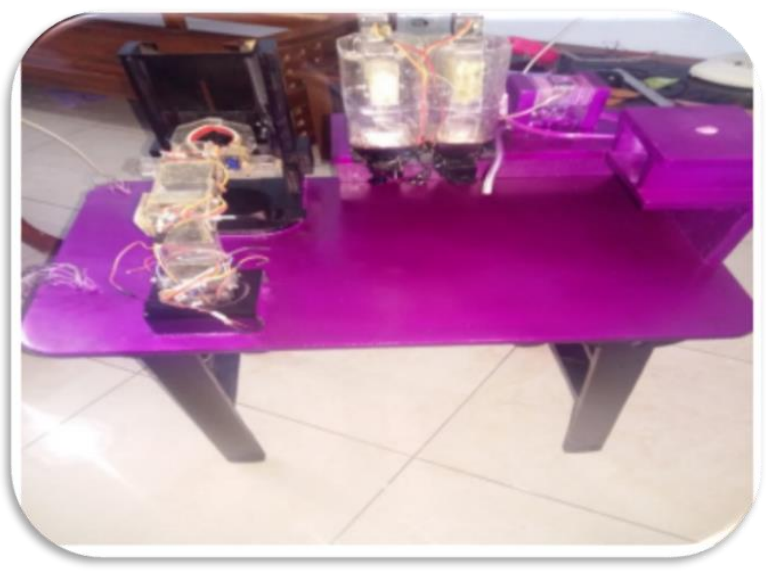

Figure 6 Prototype of the coffee maker robot arm

The coffee robot that the author is working on has different performance - on each part of the robot there are
4 processes carried out sequentially by the robot, namely: (1) The receiver part controlled by Arduino nano receives commands from the input keypad or smartphone (Bluetooth) then the command value is stored meanwhile by Arduino nano, (2) The receiver section checks the need for making coffee, namely checking the water level to determine whether or not there is water in the water container, then checks the water temperature and switches on the water heater if the water is not yet hot or gives a notification if the water is not enough to make one cup of coffee. (3) The receiver section will provide notification via voice using the mp3 module so that the user knows the process carried out by the robot. If everything is fulfilled, the receiver will issue a notification followed by giving commands to the robot arm, and (4) The robot arm that gets the command from the receiver will immediately make one cup of brewed coffee until it's finished then the arm will report to the receiver when the coffee making process is complete then the receiver will rest the robot arm and the receiver will be in its initial condition again.

\subsection{Testing}

Testing of this tool functions properly in accordance with the procedures established by the researcher. This test shows that the robot can perform the process well, namely making a cup of coffee with the right dose so that the authors ensure that the robot's performance is in the best condition for now.

\subsection{Revision and Evaluation}

Revision and evaluation at this stage is to replace the power supply so that the existing servo can run smoothly

\section{CONCLUSION}

Automatic coffee makers not only use a coffee machine but can also be used robot arm.

\section{ACKNOWLEDGMENTS}

Thank you to the Director of the Dharma Patria Polytechnic who has allowed research on campus and students who have helped.

\section{REFERENCES}

[1] Sudiyarto, S. Widayanti, and D. M. Kresna, "Perilaku konsumen penikmat Kopi Tubruk dan Kopi Instan,” J. Sos. Ekon. Pertan., vol. 6, no. 3, pp. 1-11, 2012.

[2] P. Muriel and J. Arauz, "Coffee and liver diseases," Fitoterapia, vol. 81, no. 5, pp. 297-305, 2010.

[3] Selvi and L. Ningrum, "Gaya Hidup Minum Kopi Dalam Pengambilan Keputusan Pembelian Kopi 
(Studi Kasus Pada Kopi Kenangan Gandaria City Jakarta)," J. Ilm., vol. 14, no. 1, pp. 23-30, 2020.

[4] K. Joesyiana, A. H. Prihastuti, and S. Al Sukri, "Analisis Kreativitas dan Inovasi Pengusaha Coffee Shop Subsektor Penikmat Kopi di Pekanbaru," Binawakya, vol. 14, no. 12, pp. 3671-3682, 2020.

[5] R. Y. Nasution, H. Putri, and Y. S. Hariyani, "Perancangan Dan Implementasi Tuner Gitar Otomatis Dengan Penggerak Motor Servo Berbasis Arduino," J. Elektro dan Telekomun. Terap., vol. 2, no. 1, pp. 83-94, 2016, doi: 10.25124/jett.v2i1.96.

[6] P. Prasetyawan et al., "Pengendali Lengan Robot dengan Mikrokontroler Arduino Berbasis Smartphone," J. Coding Sist. Komput. Untan, vol. 04, no. 2, pp. 104-109, 2016, doi: $10.21063 /$ jte.2018.3133715.

[7] A. P. Aigboviosa, A. Anthony, A. Claudius, S. Uzairue, S. Timilehin, and V. Imafidon, "Arduino based solar tracking system for energy improvement of PV solar panel," Proc. Int. Conf. Ind. Eng. Oper. Manag., vol. 2018, no. SEP, pp. 2469-2478, 2018.

[8] A. Beltran Jr, K. J. Dizon, K. Nones, R. L. Salanguit, J. Bhie Santos, and J. Rei Santos, "Arduino-based Disaster Management System," J. Robot. Control, vol. 2, no. 1, pp. 24-28, 2020, doi: $10.18196 /$ jrc. 2147 .

[9] P. D. O. Shirsath, P. Kamble, R. Mane, A. Kolap, and P. R. S. More, "IOT Based Smart Greenhouse Automation Using Arduino," Int. J. Innov. Res. Comput. Sci. Technol., vol. 5, no. 2, pp. 234-238, 2017, doi: 10.21276/ijircst.2017.5.2.4.

[10] D. K. Rath, “Arduino Based : Smart Light Control System,” Int. J. Eng. Res. Gen. Sci., vol. 4, no. 2, pp. 784-790, 2016. 